\title{
Publisher Correction: IgG1 memory B cells keep the memory of IgE responses
}

\author{
Jin-Shu He ${ }^{1}$, Sharrada Subramaniam,2, Vipin Narang ${ }^{1}$, Kandhadayar Srinivasan', Sean P. Saunders ${ }^{3}$,

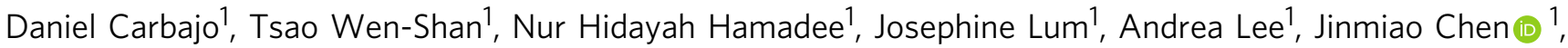 \\ Michael Poidinger (iD ${ }^{1}$, Francesca Zolezzi ${ }^{1,4}$, Juan J. Lafaille ${ }^{5}$ \& Maria A. Curotto de Lafaille (i) 1,3
}

Correction to: Nature Communications https://doi.org/10.1038/s41467-017-00723-0, published online 21 September 2017

The originally published version of this Article contained errors in Fig. 4 that were introduced during the production process. In panel c, the two uppermost labels 'IgE spleen' and 'IgE BM' incorrectly read 'IgG1 spleen' and 'IgE1 BM', respectively. These errors have now been corrected in both the PDF and HTML versions of the Article.

Published online: 01 March 2018

\begin{abstract}
(c) Open Access This article is licensed under a Creative Commons Attribution 4.0 International License, which permits use, sharing, adaptation, distribution and reproduction in any medium or format, as long as you give appropriate credit to the original author(s) and the source, provide a link to the Creative Commons license, and indicate if changes were made. The images or other third party material in this article are included in the article's Creative Commons license, unless indicated otherwise in a credit line to the material. If material is not included in the article's Creative Commons license and your intended use is not permitted by statutory regulation or exceeds the permitted use, you will need to obtain permission directly from the copyright holder. To view a copy of this license, visit http://creativecommons.org/licenses/by/4.0/.
\end{abstract}

(c) The Author(s) 2018

\footnotetext{
${ }^{1}$ Singapore Immunology Network (SlgN), 8A Biomedical Grove, Singapore 138648, Singapore. ${ }^{2}$ School of Biological Sciences, Nanyang Technological University, 60 Nanyang Drive, Singapore 637551, Singapore. ${ }^{3}$ Division of Pulmonary, Critical Care and Sleep Medicine, Departments of Medicine and Cell Biology, New York University School of Medicine, 550 First Ave, NY 10016, USA. ${ }^{4}$ Galderma R\&D, Les Templiers, 2400 route des Colles, Sophia Antipolis 06410 Biot, France. ${ }^{5}$ Skirball Institute and Department of Pathology, New York University School of Medicine, 540 First Ave, NY 10016, USA.

Correspondence and requests for materials should be addressed to M.A.C.d.L. (email: maria.lafaille@med.nyu.edu)
} 